\title{
Using MIDI and the Drill Method to Improve Student Singing Ability at SMK Negeri 2 Maros
}

\author{
Sri Wahyuni Syukur ${ }^{1}{ }^{*}$ Dr. Dra Kun Setyaning Astuti ${ }^{2}$, Nurul Fathimatul Izzah ${ }^{1}$ \\ ${ }^{1}$ Master of Arts Education, Yogyakarta State University, Yogyakarta, Indonesia \\ ${ }^{2}$ Graduate School, Yogyakarta State University, Yogyakarta, Indonesia \\ *Corresponding author. Email: sriwahyunisyukur123@gmail.com
}

\begin{abstract}
This research is conducted by implementing the Drill Method and using learning media, namely MIDI, as an alternative medium used which contains the resulting scale intervals so that it is more practical to teach, especially in improving vocal techniques in singing. The research participants are 20 students-members of the choir extracurricular program in State Vocational High School SMKN 2 Maros. This mixed qualitative and quantitative research aims to determine students' singing ability. The data were collected through observations, interviews, documentation analysis, and tests. There were two cycles conducted in this research. Each cycle consisted of some stages, namely planning, implementing, observing, and reflecting. The results of this research show that the drill method can improve student ability in singing. Based on the result collected in cycle 1, only 55\% of students are in the Good and Excellent categories in terms of singing ability. Then, in cycle 2, $80 \%$ of the students are in the Good and Excellent categories. Thus, there seem to be positive changes in students' attitudes.
\end{abstract}

Keywords: Drill method, MIDI, Extracurricular Program

\section{INTRODUCTION}

Education is an effort to develop students' physical potentials, intention, sense, and passion to create something. Through education, those aspects will be developed and will benefit the students' lives. The basis of education is a solid foundation for everyone to be able to change attitudes and behaviors through practicing and learning. Education is not limited to the school environment so that even after finishing school, students should learn from what they find outside the school.

The concept of education is developed through a teaching and learning process mechanism called school. School is a place to study so that students have both academic and non-academic knowledge. Besides, school functions as a place of self-development, creativity development, and building character.

One of the efforts to achieve good school management is by conducting extracurricular activities. Extracurricular program is an educational activity conducted after school hour. It aims to develop students' potential, talents, and interests through activities that are specifically organized by students and/or educational staff. SMK Negeri 2 Maros is one of the vocational high schools located in Maros district. All learning activities conducted at this school is based on the 2017 revised curriculum. Learning done at this school is conducted in intra-curricular and extracurricular activities.

The students are quite active in participating in extracurricular activities, especially those related to arts. The choir is one of the art extracurricular activities conducted once a week. The material provided by the coach in the choir extracurricular activities is the national songs to be sung during the flag ceremony. The song is performed in unison with one voice consisting of only female members. The choir sings the national anthem to create certain atmospheres which make the students remind and increase the sense of patriotism. The song will remind them of the heroes struggling to fight for the Indonesian independence. 
Based on the observation conducted by the researchers, many students are interested in choir extracurricular activities. The members of the choir have the ability to sing, but their ability in singing in chorus needs to be improved. To sing in a chorus, there are singing indicators to consider, including respiration, resonance, phrasing, articulation, interpretation, timbre, and several other supporting indicators. Singing in a mix of voices is said to be combined if only the color (timbre) of the singer's voices blends perfectly.

It was found that some members of the choir had lack of ability in controlling their breath when singing. They took a breath at the wrong time and not in accordance with the song notation. They had poor articulation, so the lyrics sung were be clearly listened to. Then, in terms of interpretation, they could not convey the song lyrics well. These are probably because the process and steps in the training and the knowledge given by the singing coach were not able to improve their singing skills. Thus, strategies and methods were needed to improve their skills and achieve good results, especially in singing in a choir.

This research used the drill method to improve students' singing abilities in the choir. Based on the facts and problems found, the researchers tried to use MIDI to improve students' singing ability through the drill method.

\section{LITERATURE REVIEW}

\subsection{MIDI}

MIDI (Musical Instrument Digital Interface) is a file containing only the scale of the audio which is then translated by the instrument interface of an Audio processor/encoder. The diversity of scales produced or what can be heard depends on the number of channels of the sound card/audio processor used [2]. In other words, MIDI is the language used by musical instruments.

\subsection{Drill Method}

The drill is a method used by providing repeated inputs in training to achieve dexterity or skills in doing something. Students need to be practically trained by teachers to perform well. For this reason, it is necessary to understand what situations the singing coach should do [3]. Moreover, the drill method requires practice to master certain skills [8].

\section{RESEARCH METHOD}

The quantitative research method was used to examine the improvement of students' singing ability. Meanwhile, the qualitative descriptive was used to describe activities during learning using MIDI and the applied drill method. The steps taken in implementing the applied drill method using MIDI are to provide vocalizing material. At the vocalizing stage, the students were given instructions to follow the MIDI's intervals' note. Then, students begin practicing based on the instructions given by repeating the Drill by adjusting the MIDI tone intervals.

The participants of this research were 20 eleventhgrade students joining the choir. The data were collected using the following methods.

\subsection{Interview}

In the context of educational research, data may be collected in the form of experiences, activities, interactions, teacher performance, or the culture that takes place in a particular school. Informal interviews can be conducted with teachers, certain students, school principals, school committees, local community leaders, or students' parents [7]. Researchers conducted interviews with extracurricular organizers, the singing coach, and art teachers at the school.

\subsection{Observation}

Observation is a data collection technique done by conducting thorough research and systematic recording [1]. Observation was carried out in the extracurricular activities. Focusing on the process, the researchers observed students' singing ability and vocal techniques.

\subsection{Documentation}

Documentary study (Documentation) is a data collection technique performed by collecting and analyzing documents, both written documents, and photographs [6]. Documentation was carried out to obtain secondary data in order to complement missing data, which has not been obtained through literature study and observation.

\subsection{Performance Test}

Tests measure students' learning achievement. Test types vary according to the time they are conducted [5. In this research, a performance test was conducted to measure students' abilities in singing after being taught using the drill method and MIDI as the learning media.

\section{RESULT}

This research focuses on four aspects to be measured, namely breathing, articulation, interpretation, and intonation. The criteria for the assessment is presented below.

\begin{tabular}{|l|l|l|}
\hline 1 & $=$ Poor & $(<55)$ \\
\hline
\end{tabular}




\begin{tabular}{|l|l|c|}
\hline 2 & $=$ Fair & $(57-70)$ \\
\hline 3 & $=$ Good & $(71-85)$ \\
\hline 4 & $=$ Excellent & $(86-100)$ \\
\hline
\end{tabular}

Table 1. Criteria for the Performance Test below.

The description of each category is presented

\section{Poor Category}

The students are not able to achieve abilities based on the assessment criteria. They show unstable breathing, unclear articulation, under standard intonation, and no interpretation to convey the content of the song.

\section{Fair Category}

The students are not able to master vocal techniques according to the assessment format. They show incorrect breathing technique, unclear articulation in the beginning to the end of the song, incorrect song interpretation, and incapability of singing the lyrics in accordance with the song notation.

\section{Good Category}

Students are able to demonstrate vocal techniques according to the song notation. They can manage the breathing well by showing gradual diaphragmatic breathing. They show good articulation. They have a good interpretation of the song so they can convey the lyrics well. At last, they have good intonation in accordance with the notation. The Indonesia Raya song is sung well from the beginning, climax, to the end.

\section{Excellent Category}

The students are able to perform vocal techniques in accordance with the material provided, by doing breathing techniques using diaphragmatic. Their articulation of the words is good and clear. Then, they show the proper and correct interpretation of the song. Likewise, the intonation of each sentence is clear and correct as well as in accordance with the song notation. Students are able to sing perfectly from the beginning, climax, and end of the song.

The formula used:

Score $=\frac{\text { Cumulative Score }}{\text { Number of Respondents }} \times 100 \%$

The average score is calculated using the following formula:

$$
\boldsymbol{x}=\frac{\sum X i}{N} \times 100 \%
$$

[4] Calculating the percentage of improvement. Formula to calculate the value:

$$
\text { Score }=\frac{\text { Total Score }}{\text { Number of Students }} \times 100 \%
$$

Calculating the percentage:

$$
\text { Precentage }=\frac{\text { Total students Passing the Test }}{\text { Number of Respondents }} \times 100 \%
$$

The data obtained in Cycles 1 and 2 are then compared. The results are used as the basis for examining the improvement in students' singing ability.

There are three cycles conducted in this study, namely Pre-cycle, Cycle 1, and Cycle 2 . Each cycle is carried out in stages, namely planning, implementing, observing, and reflecting. The implementation process is divided into several stages, namely, pre-activities, core activities, and final activities. The material used in learning is national song scores in the form of numbered music notation.

\subsection{Pre-cycle}

Before starting the learning activities in cycle 1 , the researchers first conducted a pre-cycle. This pre-cycle assessment aimed to show the students' initial ability in singing a song, before the implementation of the drill method. The aspects that were assessed in the pre-cycle were the same as those carried out in cycles 1 and 2, namely: (1) breathing (2) articulation (3) intonation (4) interpretation.

\subsection{Cycles 1 and 2}

In the implementation of cycle 1 , the activity was carried out twice in $2 \times 30$ minutes. The activity at the first meeting was vocalizing. Students followed the MIDI rhythm that had been prepared by the coach. This was stretching vocal cord exercise as well as light exercise for some organs that play a role when singing such as the mouth, tongue, and the throat to become more flexible. Then, breathing exercises using diaphragmatic breathing were done. The next is a breathing exercise while singing. At last, articulation exercise was done by pronouncing the consonants " $r$ ", "s", "ng" as well as vowels a, i, u, e, o. Students did those exercises repeatedly until they reach the desired goal by following the MIDI rhythm

Furthermore, the second meeting was carried out with the intonation and interpretation exercise. Students were divided into 5 groups each consisting of 5 students. At the intonation exercise, the researcher 
distributed the Indonesian Raya song scores to students before starting to sing. The researcher conducted intonation exercise for students. There are stages carried out and considered in the training, namely:

a. The first stage was singing a song based on the Indonesian Raya song notation

b. The next stage was singing songs with various tempo

c. The last stage was performing the interval in a song from low to increasing intervals starting from the beginning, climax, to the end of the song.

The next activity was the student interpretation exercise. At this stage, the researcher explained the content of the song before asking the students to sing. Then, the researchers carried out the stages in interpretation training for students by singing the Indonesian Raya song based on the tone sung, starting with the beginning of the song, the climax, to the end of the song.

The final stage was conducting a test to measure to what extent students could apply the knowledge provided by the researcher in two stages, namely song interpretation and controlling intonation by singing Indonesia Raya song. In this test, each session was carried out in a group. This final test was also performed at the breathing technique and articulation stages. In this test, researchers are able to see the level of success in each learning and the extent to which students understand and implement the knowledge they gained through the learning process in cycles 1 and 2 . Each cycle was conducted in 4 meetings conducted for $2 \times 30$ minutes each. The MIDI software used in this research is presented below.

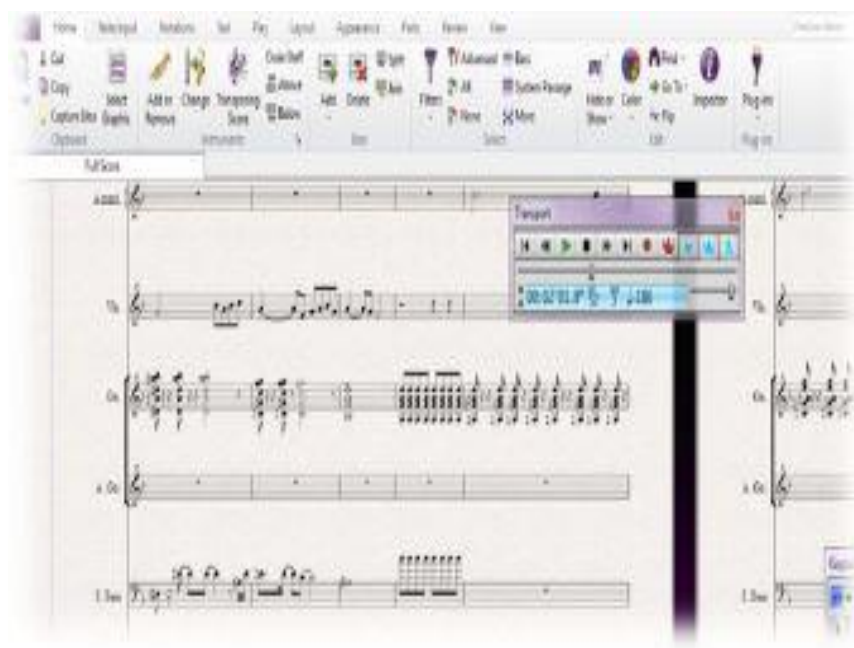

Figure 1. The MIDI Software

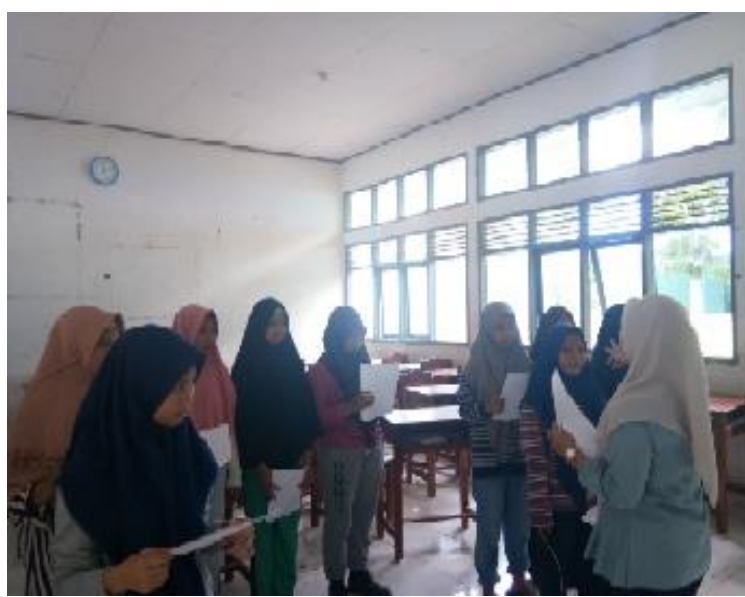

Figure 2. The Teaching-Learning Process

\subsection{The Improvement in Students' Singing Ability after the Implementation of Drill Learning Method and MIDI Learning Media (Pre-Cycle, Cycle 1, and Cycle 2)}

\begin{tabular}{|c|c|c|c|c|c|c|}
\hline \multirow{2}{*}{ Kategori } & \multicolumn{2}{|c|}{ Prasiklus } & \multicolumn{2}{|c|}{ Siklus 1} & \multicolumn{2}{|c|}{ Siklus 2} \\
\hline & 承 & 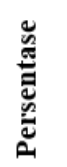 & 丞营 & 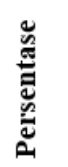 & 总营 & 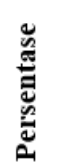 \\
\hline Sangat Baik & & & & & & \\
\hline$(86-100)$ & - & $0 \%$ & 1 & $5 \%$ & 5 & $25 \%$ \\
\hline Baik & & & & & & \\
\hline$(71-85)$ & 7 & $35 \%$ & 10 & $50 \%$ & 11 & $55 \%$ \\
\hline Cukup & & & & & & \\
\hline$(56-70)$ & 6 & $30 \%$ & 6 & $30 \%$ & 4 & $20 \%$ \\
\hline Kurang & & & & & & \\
\hline$(\leq 55)$ & 7 & $35 \%$ & 3 & $15 \%$ & 0 & $0 \%$ \\
\hline
\end{tabular}

Table 2. The Improvement during Pre-Cycle, Cycle 1, and Cycle 2

Table Description: Based on the recapitulation of the assessment results, the students' singing ability has increased. The pre-cycle results show that the students' average score is 61.85 (7 students or $35 \%$ are in the Good category, 6 students or $30 \%$ are in the Fair category, 7 students or $35 \%$ are in the Poor category, and none of the students are in the Excellent category).

In cycle 1 , students' singing ability average score is 67.05 (1 student or 5\% is in the Excellent category, 10 students or $50 \%$ are in the Good category, 6 students or $30 \%$ are in the Fair category, and 3 students or $15 \%$ are in the Poor category). Although the average score in cycle 1 increases by 5.2 points from the pre-cycle average results, it is considered unsuccessful because 
the percentage of students with the Good and Excellent categories is less than $80 \%$.

Based on the results of assessing students' singing ability in cycle 2 , the average score is 76 (5 students or $25 \%$ are in the Excellent category, 11 students or $55 \%$ are in the Good category, 4 students or $20 \%$ are in the Fair category, and no student belong to the Poor category). Based on these results, the student's success rate in improving the singing ability in the choir in cycle 2 has increased by $80 \%$. Thus, the number of students achieving the Excellent and Good categories is more than the required total. Thus, the learning method and media determined by the researcher, the drill method and MIDI, enable students to learn more through the process as they are provided with opportunities to do repeated exercises. They learn through processes, so they are capable of significantly improving. The material provided by the researcher is well accepted by the students participating in the choir extracurricular program at SMKN 2 Maros.

The teaching-learning process runs smoothly because there is two way-interaction between the teacher and students and among students. The researchers previously conducted interviews with extracurricular coaches to find information related to the students and asked for directions related to extracurricular activities at the school in order to make this research progress gradually and effectively. Based on the results of classroom action research (CAR), it can be concluded that the implementation of the drill method by utilizing MIDI as the learning media can successfully improve students' singing skills in the choir through extracurricular activities at SMK Negeri 2 Maros. It can be seen from the results of the pre-cycle that only $35 \%$ of students are in the Good category (> $70)$, but after two cycles are performed, the results increase. As many as $80 \%$ of students are in the Good and Excellent categories ( $>70)$ the cycle is considered successful. The aspects in which the researchers focused on this study are breathing, articulation, intonation, and interpretation of singing the Indonesia Raya song.

\section{CONCLUSION}

The implementation of the drill method to improve students' singing abilities using MIDI as the learning media in the choir extracurricular program at SMK Negeri 2 Maros are carried out in 2 cycles. Each cycle contains several stages, namely: Planning, Implementing, Observing, and Reflecting. During the stages, researchers provide an explanation of vocal techniques and how to sing properly and correctly in a choir. Students are taught to read numbered notations before introduced to song material. The researchers give instruction to do vocalizing exercises using MIDI as the learning media before discussing the material.
Indonesia Raya song scores are distributed to the students. The researchers assess the students who are divided into five groups, guide, and carry out performance tests with each group. The results show that the student singing ability is improved. They are able to do the exercises and show significant results in accordance with the directions given by the researchers after going through the process, namely cycle I and cycle II. The improvement can be seen from both cycles.

\section{REFERENCES}

[1] Gunawan, Imam. Metode penelitian kualitatif [Qualitative Research Methodology]. Jakarta: Bumi Aksara 143 (2013).

[2] Lesar, Yanny. Duet Vokal Duet Vokal: Dilengkapi: Not Balok, Not Angka, Lagu Pop, Lagu Daerah, Lagu Barat / Yanny Lesar Bandung: Nuansa Aulia (2013).

[3] Ratnaningsih, Enok. Efektivitas Metode Drill dan Resitasi dalam Meningkatkan Pemahaman dan Keterampilan Siswa terhadap Hukum Bacaan Qulqolah dan Ro'di SMP Negeri 1 Subang [The Effectiveness of the Drill and Recitation Method in Improving Students' Understanding and Skills of Reading Qulqolah Law and Ro'di SMP Negeri 1 Subang]. Jurnal Pendidikan Agama Islam-Ta'lim 10.1 (2012): 79-94.

[4] Sudjana, Nana. Metode Statistika. Bandung: Tarsito. Diss. tesis pengaruh pembelajaran berbasis masalah dan kreativitas terhadap hasil belajar IPA. Bogor: Pasca sarjana Teknologi pendidikan Bogor, 2002. Unpublished.

[5] Sugiyono, Sugiyono. Metode penelitian kuantitatif dan kualitatif dan R\&D [Quantitative and qualitative research methods and R\&D]. (2010).

[6] Sukmadinata, N. S. Dalam Metode Penelitian Pendidikan [Within Educational Research Methods]. Bandung: Remaja Rosdakarya (2013).

[7] Suwartono, M. Dasar-Dasar Metodologi Penelitian [Basics of Research Methodology]. Penerbit Andi, 2014.

[8] Tambak, Syahraini. Metode Drill dalam Pembelajaran Pendidikan Agama Islam [The Drill Method in Learning Islamic Religious Education]. Al-Hikmah: Jurnal Agama dan Ilmu Pengetahuan 13.2 (2016): 110-127. DOI: ttps://doi.org/10.25299/alhikmah:jaip.2016.vol13(2).1517 